THE DETERMINATION OF RICE GRAIN PRICE BY LDPM (INSTITUTE OF COMMUNITY FOOD DISTRIBUTION) AND INFLUENCE OF THE FACTORS

\author{
Jusuf Sugiharto ${ }^{1}$, Agnes Quartina Pudjiastuti ${ }^{2}$, Amir Hamzah ${ }^{3}$ \\ jusufsugiharto2018@gmail.com \\ ${ }^{1}$ Magister Student and ${ }^{2}$ Lecturer of Master of Agriculture Economics Postgraduate \\ School of Tribhuwana Tunggadewi University
}

\begin{abstract}
Various agricultural problems, both farmers' problems, farmer groups and farmer group associations have demanded government intervention, especially in the provision of capital assistance. The Government issued a program Strengthening the Institute of Food Distribution Society (P-LDPM). This study aims to determine the level of participation of farmer groups receiving P-LPDM activities and the factors that influence the effectiveness of farmer groups in supporting the stability of grain prices in LDPM activities. Research respondents were set at 100 farmers, randomly selected. Regression analysis shows that farmers 'experience, farmers' land area, labor and seeds have a positive effect on rice production, which means that when the variables increase, rice production also increases. Variables that have no significant effect on rice production are ponska fertilizer, other fertilizers and pesticides. This fertilizers were only used by some farmers..
\end{abstract}

Keywords: group of farmers, price, rice, rice grain

\title{
PENENTUAN HARGA GABAH DI TINGKAT LEMBAGA DISTRIBUSI PANGAN MASYARAKAT DAN FAKTOR YANG MEMPENGARUHINYA
}

\author{
Jusuf Sugiharto ${ }^{1}$, Agnes Quartina Pudjiastuti ${ }^{2}$, Amir Hamzah ${ }^{3}$ \\ jusufsugiharto2018@gmail.com \\ ${ }^{1}$ Mahasiswa dan ${ }^{2}$ Dosen Magister Ekonomi Pertanian Sekolah Pascasarjana \\ Universitas Tribhuwana Tunggadewi
}

\begin{abstract}
ABSTRAK
Berbagai permasalahan pertanian, baik permasalahan petani, kelompok tani maupun gabungan kelompok tani telah menuntut adanya campur tangan pemerintah khususnya dalam pemberian bantuan modal. Pemerintah mengeluarkan program Penguatan Lembaga Distribusi Pangan Masyarakat (P-LDPM). Penelitian ini bertujuan untuk mengetahui tingkat peran serta kelompok tani penerima kegiatan P-LPDM dan faktor-faktor yang mempengaruhi terhadap efektivitas kelompok tani dalam menunjang stabilitas harga gabah pada kegiatan LDPM. Responden penelitian ditetapkan sebesar 100 petani, yang dipilih secara acak. Analisis regresi menunjukkan bahwa pengalaman petani, luas lahan garapan petani, tenaga kerja dan bibit berpengaruh positif terhadap
\end{abstract}


produksi padi yang artinya apabila variabel-variabel tersebut semakin bertambah maka produksi padi juga semakin meningkat. Variabel yang tidak berpengaruh signifikan terhadap produksi padi adalah pupuk ponska, pupuk lainnya dan pestisida. Pupuk ini hanya digunakan oleh sebagian petani.

Kata kunci : Kelompok tani, harga, beras, gabah 


\section{PENDAHULUAN}

\begin{abstract}
Pangan merupakan kebutuhan pokok yang bersifat mendasar sehingga memiliki sifat strategis dalam pembangunan baik pada tingkat wilayah maupun nasional. Untuk mewujudkan ketersediaan pangan yang cukup bagi seluruh penduduk dan menjamin agar setiap rumah tangga mendapatkan akses terhadap pangan sesuai kebutuhannya yang terakumulasi pada pembangunan ketahanan pangan nasional (Akbar, 2012).
\end{abstract}

Guna mengatasi permasalahan yang dihadapi oleh petani, kelompok tani atau gabungan kelompok tani (gapoktan), pemerintah mengakolasikan Kegiatan Penguatan Lembaga Distribusi Pangan Masyarakat (P-LDPM) bertujuan sebagai lembaga ekonomi petani, peningkatan ketahanan pangan masyarakat diharapkan mampu membantu petani dalam menjaga stabilitas dan berperan sebagai pembeli gabah/ beras minimal pada tingkat Harga Pembelian Pemerintah (HPP) dan dapat mengelola gabah/ beras tersebut. Hal ini hendaknya bias diantisipasi dengan pengelolaan yang baik (Purwanto, 2011).

Penguatan-LDPM merupakan kegiatan dalam rangka meningkatkan kemampuan gapoktan di wilayah sentra produksi padi dan jagung agar mampu membantu anggota gapoktan dalam mendistribusikan, memasarkan, mengelola hasil produksi pangan saat menghadapi panen raya dan mampu menyediakan saat paceklik. Selain itu, sebagai respon dari adanya perubahan lingkungan strategis secara global yang ditandai oleh pergerakan hargaharga pangan strategis, yang menurut
Pudjiastuti (2014) akan mempengaruhi neraca perdagangan. Perdagangan global yang mensyaratkan penghapusan hambatan perdagangan akan berpengaruh terhadap harga komoditas domestik.

Tujuan utama dari P-LDPM: 1) kemampuan kelembagaan gapoktan, 2) unit usaha distribusi dan pengolahan hasil pertanian dalam rangka mendorong stabilitas harga pangan strategis, 3) kemampuan unit usaha distribusi dan pemasaran, 4) unit cadangan pangan dengan tersedianya gudang gapoktan untuk menyimpan gabah/ beras dalam rangka memenuhi kebutuhan anggota (BKP, 2015).

Samsi (2012) menyatakan peran serta kelompok tani sangatlah dibutuhkan sebagai elemen kelembagaan di tingkat petani penentu keberhasilan dalam kegiatan P-LDPM karena peran serta aktif dan kerjasama yang dilakukan baik sesama anggota kelompok tani akan menentukan kinerja dari gapoktan penerima program tersebut sebagai penentu stabilitas harga di tingkat gapoktan.

Peningkatan produksi beras men-jadi perhatian pemerintah. Kebijakan yang digunakan adalah penetapan harga pem-belian pemerintah yang memiliki tiga fungsi strategis yang dapat memberikan perlindungan bagi petani produsen dan konsumen. Fungsi kebijakan harga pertama untuk menjaga stabilitas atau mengurangi fluktuasi harga antar musim antar wilayah, fungsi kedua memberikan insentif atau signal positif yang dapat membantu petani merencanakan pola produksi pada musim tanam yang akan datang, ketiga sebagai acuan kepastian bagi konsumen beras, terutama dari 
kalangan tidak mampu (Widiarsih, 2012).

Melalui kebijakan harga gabah/ beras, diharapkan petani mendapatkan harga jual yang lebih baik sehingga mampu meningkatkan pendapatan. HPP ditetapkan dengan dasar hokum Instruksi Presiden yang secara rutin diberlakukan untuk merespon dinamika yang terjadi.

\section{TINJAUAN PUSTAKA}

\section{Program Penguatan Lembaga} Distribusi Pangan Masyarakat (PLPDM)

Poktan dan gapoktan sering dihadapkan pada berbagai masalah, antara lain keterbatasan modal usaha untuk melakukan kegiatan pengolahan, penyimpanan dan pemasaran sehingga tidak memiliki cadangan pangan. Pada saat panen raya harga pangan jatuh, karena ketidakmampuan poktan dan gapoktan untuk mendistribusikan ke luar wilayah sebagai akibat sering kekurangan pangan pada saat musin paceklik. Menurut Purwanto (2011), Penguatan Lembaga Distribusi Pangan Masyarakat (P-LDPM) adalah program unggulan untuk peningkatan ketahanan pangan yang diharapkan mampu memberdayakan bisnis pangan bagi petani di pedesaan, meningkatkan daya beli, memperkuat posisi tawar petani, meningkatkan akses pangan, serta pemanfaatan peluang pengembangan produk agribisnis ekonomi tinggi dan ramah lingkungan. Selain itu gapoktan dapat mengembangkan usaha ekonomi di wilayahnya dengan meningkatkan volume pembelian atau penjualan gabah beras/jagung sehingga meningkatkan modal usaha gapoktan dan meningkatkan nilai tambah produk melalui kegiatan penyimpanan, pengolahan, dan pengepakan. Gapoktan juga harus memperluas jejaring kemitraan distribusi/ pemasaran yang saling menguntungkan dengan mitra usaha di dalam maupun di luar wialayah gapoktan.

Pelaksanaan P-LDPM dimaksudkan untuk mewujudkan stabilitas harga pangan di tingkat petani pada saat menghadapi panen raya serta mewujudkan ketahanan pangan di tingkat rumah tangga petani pada saat musim paceklik dengan kegiatan: 1) pengembangan unit usaha distribusi, pemasaran, pengolahan, dan pengelolaan cadangan pangan, dan 2) pembangunan sarana penyimpanan. Hal ini dimaksudkan agar gapoktan dapat meningkatkan posisi tawar petani, meningkatkan nilai tambah produksi petani dan mendekatkan akses terhadap sumber pangan.

Strategi dasar dalam pelaksanaan kegiatan P-LDPM antara lain: 1) memperkuat modal usaha gapoktan untuk dapat melakukan kegiatan pembelian dan penjualan gabah, baik beras ataupun jagung, terutama dari hasil petani anggota, 2) membangun sarana penyimpanan dan pengadaan cadangan pangan, 3) memberikan pendampingan kepada gapoktan agar mampu mengembangkan dan mengelola unit usaha dengan baik, 4) meningkatkan kemampuan sumber daya manusia gapoktan dalam mengadministrasikan kegiatannya, dan 5) membuat laporan secara rutin. Untuk dapat memenuhi persyaratan, gapoktan harus memenuhi kriteria sebagai berikut: 1) berlokasi di daerah sentra produksi padi dan jagung, 2) memiliki unit usaha distribusi, pemasaran, dan unit 
pengolahan cadangan pangan serta memiliki lahan sendiri untuk membangun sarana penyimpanan (gudang). Upaya dilakukan pada kegiatan P-LDPM: 1) mendukung agar petani memperoleh harga produksi yang lebih baik disaat panen raya, 2) meningkatkan kemampuan petani memperoleh nilai tambah produksi pangan dan usahanya melalui kegiatan pengolahan, pengepakan, serta pemasaran sehingga terjadi perbaikan pendapatan di tingkat petani, dan 3) memperkuat kemampuan gapoktan dalam melakukan pengolahan cadangan pangan sehingga mampu mendekatkan akses pangan pada saat menghadapi paceklik kepada anggota petani yang tergabung dalam wadah gapoktan.

\section{Organisasi serta Kinerja Gabungan Kelompok Tani (Gapoktan) dan Kelompok Tani (Poktan)}

Gabungan kelompok tani (gapoktan) sebagai kumpulan beberapa kelompok tani yang tergabung dan bekerja sama untuk meningkatkan skala ekonomi dan efisiensi usaha. Gapoktan terdiri atas kelompok tani yang ada dalam wilayah suatu wilayah administrasi desa atau yang berada dalam suatu wilayah aliran irigasi petak perairan tersier. Gapoktan adalah gabungan dari beberapa kelompok tani yang melakukan usaha agribisnis di atas prinsip kebersamaan dan kemitraan sehingga mencapai peningkatan produksi dan pendapatan usaha tani bagi anggotanya dan petani lainnya. Pengembangan gapoktan dilatarbelakangi oleh kenyataan lemahnya akses petani terhadap berbagai kelembagaan layanan usaha. Pada prinsipnya lembaga gapoktan diarahkan sebagai sebuah lembaga ekonomi, namun diharapkan juga mampu menjalankan fungsi-fungsi lainnya serta memiliki peran penting terhadap pertanian. Peran kelembagaan sangat penting dalam mengatur sumber daya dan distribusi manfaat, unsur kelembagaan perlu diperhatikan dalam upaya peningkatan potensi desa guna menunjang pembangunan desa. Dengan adanya kelembagaan petani dan ekonomi desa sangat terbantu dalam hal mengatur silang antar pemilik input dalam menghasilkan output ekonomi desa dan dalam mengatur distribusi output tersebut.

Menurut Sandyatma (2012), kelembagaan petani sebagai sasaran penerima manfaat seperti petani, kelompoktani dan gapoktan diperlukan dalam menentukan keberhasilan kegiatan P-LDPM. Partisipasi petani yang tergabung dalam wadah gapoktan menjadi penting posisinya dalam kegiatan ini karena keterlibatan aktif dan kerjasama yang dilakukan baik dengan sesama anggota maupun pengurus gapoktan akan menentukan kinerja efektivitas gapoktan itu sendiri. Aktifitas kelompok tani dalam gapoktan dalam keseluruhan proses kegiatan yang mencakup: pengambilan keputusan dalam perencanaan, pelaksanaan kegiatan, pemantauan dan evaluasi, serta pemanfaatan hasil kegiatan yang dicapai. Peran serta dan keterlibatan aktif anggota apoktan pada kegiatan P-LDPM akan menentukan keberhasilan gapoktan dalam mencapai tujuannya, efektivitas gapoktan pada dasarnya ditentukan dari akumulasi yang dilakukan oleh anggotanya. Apabila setiap anggota gapoktan berkoordinasi melakukan tugas dan fungsinya masing-masing 
dengan baik, maka gapoktan secara keseluruhan akan muncul. Proses tercapainya tujuan gapoktan dalam kegiatan ini meliputi :

a. Tersalurnya dana bansos untuk pembangunan gudang,

b. Proses meningatnya dana bansos melalui perputaran aktif pembelian dan penjualan gahab/beras gapoktan dari petani anggotanya.

c. Tersedianya cadangan pangan untuk memenuhi kebutuhan anggotanya.

\section{Kebijakan Harga Gabah/Beras}

Kebijakan harga
gabah/beras merupakan salah satu
instrumen penting dalam menciptakan
ketahanan pangan nasional Beragamnya kualitas gabah di tingkat petani tercermin pada musim dan waktu yang sama terjadi variasi harga yang cukup berbeda antara petani. Fenomena ini sesungguhnya menginformasikan bahwa pada kenyataannya gabah dengan kualitas yang baik sudah sepantasnya dihargai lebih mahal dari kualitas yang kurang baik. Namun permasalahannya belum ada kesepakatan yang sama antara pedagang dan petani tentang perbedaan kualitas tersebut dan berapa perbedaan minimal harga tersebut agar mampu mendorong petani untuk meningkatkan kualitas gabahnya. Posisi penentu kualitas dan harga masih didominasi oleh pedagang, sehingga petani lebih bersifat menerima saja. Melalui kebijakan HPP pada gabah dan beras diharapkan adanya kejelasan dan jaminan harga menurut mutu kualitas yang dihasilkan petani. Perbedaan kualitas berdasarkan persepsi petani dan pedagang, terlihat adanya komunikasi yang tidak simetris dalam bertransaksi. Hal ini ternyata berdampak buruk terhadap petani dalam bertransaksi. Pedagang dalam betransaksi adalah perbedaan kualitas gabah/beras berdasarkan jenis butiran panjang dan butiran pendek-bulat. Butiran panjang dipahami sebagai kualitas gabah/beras yang lebih baik dan lebih mahal di pasaran dibandingkan butiran pendek-bulat. Kualitas butiran gabah/beras panjang atau pendek ini dapat berasal dari varietas padi yang berbeda.

Di tingkat petani, pengelompokkan kualitas beras menjadi dua yaitu medium dan premium, maka usaha tani padi dapat juga dikelompokkan menjadi kelompok usaha tani padi yang menghasilkan beras premium dan siasanya adalah kelompok usaha tani yang hanya mampu menghasilkan kualitas medium. Dengan HPP, maka gabah yang dihasilkan usaha tani kelompok premium akan mendapatkan harga yang relatif baik, sebaliknya usaha tani pada kelompok medium akan mendapatkan harga yang sesuai. Kebijakan HPP ini akan merangsang petani yang tadinya menghasilkan gabah kualitas medium menjadi menjadi kualitas lebih baik (premium). Faktor yang mempengaruhi harga (gabah/beras) antara lain:

a. Luas Panen

Luas panen ini merupakan agregasi dari luas panen padi sawah, semakin banyak panen maka berpengaruh pada harga beras di pasar domestik dan akan memberikan dampak terhadap penguatan nilai tukar rupiah. Peningkatan produksi menjadi perhatian pemerintah, bila dicermati kebijakan tersebut senantiasa menggunakan instrumen teknologi dan ekonomi. Instrumen teknologi yang dipakai adalah perbaikan teknologi 
(revolusi hijau) dan perluasan areal melalui program ekstensifikasi, instrumen ekonomi meliputi penetapan harga pembelian pemerintah, stabilitas harga petani dan harga konsumen, penetapan harga eceran tertinggi serta subsidi pupuk dan subsidi bunga kredit usaha tani.

b. Konsumsi Beras Jumlah

Konsumsi beras dipengaruhi oleh perubahan jumlah penduduk, semakin banyak jumlah penduduknya kebutuhan per kapita akan semakin meningkat. Jumlah penduduk penduduk 2.544.315 jiwa (BKP3 Kab. Malang, 2015), kebutuhan beras 89,49 $\mathrm{kg} / \mathrm{kap} / \mathrm{tahun}$ (Susenas 2013). Diversifikasi pangan merupakan pilar utama dalam mewujudkan ketahanan pangan. Melalui diversifikasi pertanian pendapatan petani dapat meningkat, hal ini artinya kesejahteraan petani juga akan meningkat. Selain itu pola pikir yang menganggap "belum makan kalau belum makan nasi" secara bertahap harus diubah. Kondisi geografis yang berbeda dari barat ke timur menyebabkan jenis tanah, jumlah air dan suhu di daerah berbeda. Padi bukan tanaman yang bisa ditanam di mana saja. Oleh karena itu, tidak perlu memaksakan mengkonsumsi nasi sebagai makanan pokok karena masih ada ubi, sagu, singkong dan jagung yang bisa dikonsumsi.

c. Harga Beras Domestik

Harga ini merupakan harga beras rata-rata kualitas medium di pasar dari total produksi padi. Menurut Rahmanto (2012), kebijakan harga dasar gabah yang kemudian diubah dengan harga pembelian pemerintah, dilakukan dengan tujuan untuk memberikan insentif kepada petani yang diharapkan dapat mendorong perluasan areal tanam dan penggunaan teknologi lebih baik dalam budidaya tanaman yang pada gilirannya akan meningkatkan pendapatan petani. Melalui kebijakan harga dasar gabah, diharapkan petani mendapatkan harga jual yang lebih baik. Harga dasar gabah ditetapkan dengan dasar hukum Instruksi Presiden yang secara rutin diberlakukan untuk merespon dinamika yang terjadi yang bila dicermati dari tahun ke tahun mengalami peningkatan sebagai upaya mengantisipasi kenaikan biaya produksi, perkembangan pasar beras dan kenaikan inflasi.

\section{METODE PENELITIAN}

Penelitian dilakukan di Kabupaten Malang karena wilayah ini merupakan sentra padi di Jawa Timur. Populasi penelitian merupakan seluruh petani anggota gapoktan pelaksana kegiatan P-LDPM. Sampel dipilih secara acak (simple random sampling) sebanyak 100 petani. Kriteria responden: 1) Pasca Mandiri sebanyak 2 gapoktan, 2 kelompok tani, 20 petani, 2) Mandiri sebanyak 2 gapoktan, 2 kelompok tani, 20 petani, 3) Pengembangan sebanyak 1 gapoktan, 1 kelompok tani, 10 petani, dan 4) kriteria umur $30-50$ tahun. Penelitian ini menggunakan metode survey di Kabupaten Malang dengan purposive sampling berdasarkan pengamatan di lapangan karena tidak semua anggota kelompok tani mengetahui kegiatan LDPM meskipun mereka ikut serta dalam kegiatan. Data yang diperlukan terdiri atas data primer yang diperoleh dari wawancara, pengisian kuesioner dengan anggota kelompok tani dan data sekunder yang di peroleh dari dinas instansi terkait. Analisis data 
dilakukan secara kuantitatif dengan menggunakan analisis regresi.

\section{HASIL DAN DISKUSI \\ Hasil Analisis Regresi Pengaruh Program P-LDPM Terhadap Harga Padi}

Hasil analisis regresi
menunjukkan bahwa kontribusi
kepesertaan petani dalam program
LDPM terhadap variasi harga padi
adalah sebesar $17 \%$. Kontribusi relatif
besar mengingat bahwa 93\% di
antaranya telah dijelaskan oleh 8
variabel yang telah dianalisis
sebelumnya. Dengan demikian model
ini dapat dikatakan telah sesuai
(goodness of fit).

Hasil analisis regresi juga menunjukkan bahwa kepesertaan petani dalam program LDPM berpengaruh signifikan dan positif terhadap harga padi. Petani yang mengikuti program LDPM akan menikmati manfaat kenaikan harga padi. Sebaliknya jika petani tidak mengikuti program LDPM, maka petani tidak akan menerima manfaat berupa harga padi yang lebih tinggi.

Pangan merupakan salah satu kebutuhan manusia yang cukup mendasar, dianggap strategis dan sering mencakup hal-hal yang bersifat emosional dan bahkan politis. Terpenuhinya kebutuhan pangan secara kualitas dan kuantitas merupakan hal yang sangat penting sebagai landasan bagi pembangunan manusia seutuhnya dalam jangka panjang. Keadaan ini tercermin dari berbagai bentuk intervensi yang dilakukan pemerintah disektor pengan terutama beras, seperti intervensi pemerintah di sektor pertanian dan pengembangan teknologi usaha tani terutama kebijakan harga.

Harga adalah sejumlah nilai yang ditukarkan oleh konsumen yang mengambil manfaat dari memiliki atau menggunakan produk atau jasa dimana nilainya ditetapkan oleh penjual dan pembeli melalui tawar menawar atau ditetapkan oleh penjual untuk satu harga yang sama terhadap semua pembeli (Karmini, 2005; Anindita, 2011). Harga merupakan pokok dalam perumusan pemasaran. Penetapan harga dapat berbeda ditempat yang berbeda karena disebabkan beberapa faktor yaitu : kualitas barang, musim dan aksebilitas. Diketahui bahwa terdapat perbedaan kualitas dan jumlah hasil panen yang diperoleh pada musim hujan dan musim kemarau. Dengan kriteria pengukuran yang sama antar musim, jumlah hasil panen lebih banyak musim hujan dibandingkan musim kemarau, tetapi kualitas gabah dan beras pada musim kemarau lebih baik dari musim hujan, karena kualitas gabah merupakan salah satu faktor penting dalam menentukan kualitas beras, maka kualitas gabah yang secara umum lebih baik pada musim kemarau perlu diperbanyak kualitasnya, yang berarti pasca panen harus ditingkatkan.

Harga dapat dilihat dari segi penawaran maupun permintaan. Secara umum bila harga tinggi, hanya sedikit orang yang mau dan mampu membeli yang ada di pasar sangat besar, sedangkan permintaan beras relatif stabil sepanjang tahun, tentu pada saat itu harga akan rendah karena jumlah penawaran lebih besar dari jumlah permintaan. Peluang mendapatkan barang (beras) pada saat panen raya sangat besar akan tetapi peluang memasarkan relatif kecil 
karena banyaknya pesaing, sebaliknya pada musim paceklik peluang mendapatkan beras sangat kecil tetapi peluang memasarkan lebih besar. Hal ini disebabkan sifat permintaan beras yang inelastic yaitu permintaan beras tidak dipengaruhi oleh harga beras yang berlaku. Ketersediaan beras dipasaran akan dipengeruhi harga beras di pasar sedangkan harga beras akan mempengaruhi peluang pasar itu sendiri. Program P-LDPM mampu memecahkan permasalahan ini dengan tetap membeli harga minimal sesuai dengan HPP yang sudah ditetapkan oleh pemerintah. Sebaliknya yang tidak mengikuti program maka akan mendapatkan harga sesuai dengan harga yang ditawarkan oleh pasar.

\section{KESIMPULAN}

Kesimpulan dari penelitian ini, sebagai berikut :

1. Harga merupakan pokok dalam perumusan pemasaran, penetapan harga dapat berbeda ditempat yang berbeda dan harga akan mempengaruhi peluang pasar itu sendiri karena disebabkan beberapa faktor yaitu : kualitas barang, musim dan aksebilitas,

2. Dari analisis regresi linier berganda didapatkan bahwa hubungan bibit, pupuk umur dan keanggotaan kelompok tani terhadap produksi gabah adalah positif dan berhubungan erat begitu pula pengalaman dalam berusaha tani, nilai pengalaman petani harus ditunjang dengan tingkat pendidikan yang dimiliki.

3. Penguatan Lembaga Distribusi Pangan Masyarakat (P- LDPM) sebagai program unggulan peningkatan ketahanan pangan mampu memperdayakan bisnis pangan bagi petani di pedesaan, meningkatkan daya beli, memperkuat posis tawar petani, meningkatkan akses pangan dengan meningkatkan volume pembelian atau penjualan, meningkatkan nilai tambah produk, memperluas jejaring kemitraan distribusi/ pemasaran.

4. Kelompok tani sebagai wadah dari petani mempunyai peran serta sangat positip dengan P-LDPM yang merupakan bagian dari upaya peningkatan ketahanan pangan masyarakat mampu membantu petani dalam menjaga stabilitas harga yakni dengan membeli hasil dari anggota kelompok tani.

\section{Saran}

Berdasarkan kesimpulan, maka disarankan beberapa hal sebagai berikut :

1. Penetapan harga gabah/ beras harus menjadi perhatian pemerintah, karena kondisi yang terjadi di pasar tergantung pada tingkat harga dasar yang berlaku.

2. Peningkatan produktivitas dan pendapatan petani dapat dilakukan dengan pengelolaan usahatani dalam penggunaan faktor produksi terutama benih yang baik.

3. Program LDPM untuk tetap di teruskan karena merupakan salah satu upaya memotong mata rantai alur distribusi di pedesaan yang dapat menjaga stabilitas harga gabah di tingkat petani, agar tidak jatuh pada saat panen raya.

4. Gapoktan/ Kelompok tani sebagai wadah menampung aspirasi dan kebutuhan yang diperlukan oleh anggotanya, sehingga anggota 
dapat terlibat penuh dalam semua kegiatan menuju kegiatan yang dituju/ dicapai, diperlukan pemimpin muda, inovatif dan kreaktif.

\section{DAFTAR PUSTAKA}

Akbar Fikri M, 2012. Efektifitas Komunikasi dalam

Pelaksanaan Kegiatan

Penguatan Lembaga Distribusi Pangan Masyarakat. ( Kasus Gapoktan Maju Bersama Desa Bumiharjo Kecamatan Batanghari Kabupaten Lampung Timur ) Staf Pengajar Ilmu FISIP universitas Sang Bumi Ruwa Jurai, Jurnal Sosiologi Vol,16.No.2 : 115-126.

Anindita, R; Heryanto; Pudjiastuti, A.Q.; Rozy, F. 2011. Ekonomi Pertanian. Universitas Terbuka.

(BKP) 2015 Badan Ketahana Pangan Kementrien Pertanian. Pedoman Teknis Kegiatan Penguatan Lembaga Distribusi Pangan Masyarakat.

Pudjiastuti, A.Q. 2014. Perubahan Neraca Perdagangan Indonesia sebagai Akibat Penghapusan Tarif Impor Gula. Agriekonomika Vol 3 No 2, hal 106-116.

Purwanto, H. 2011. Tesis Pemikiran Pengembangan Asosiasi Lembaga Distribusi Pangan Masyarakat (LDPM) ke depan.

Samsi Sumarru H, 2012. Partisipasi Anggota Kelompok Tani dalam Menunjang Efektivitas Gapoktan pada Kegiatan Penguatan Lembaga Distribusi Pangan Masyarakat di
Kabupaten Bogor. Jurnal Vol.2 No. 3 Hal 225- 328

Sandyatma, H.S., 2012. Partisipasi Anggota Kelompok Tani dalam Menunjang Efektivitas Gapoktan Pada Kegiatan Lembaga Distribusi Pangan Masyarakat di Kabupaten Bogor. Tesis, Universitas Gadjah Mada.

Widiarsih Dwi. 2012. Pengarus Sektor Komodite Beras Terhadap Inflasi Bahan Makanan. Jurnal Sosial Ekonomi Pembangunan. Tahun II No. 6 Juli 2012 
